\title{
Hematophagous Flies in Dhofar (Sultanate of Oman): A Limiting Factor and a Potential Pathogenic Vector
}

\author{
Ali Tigani EIMahi* \\ Department of Archaeology, College of Arts and Social Sciences \\ Sultan Qaboos University, P.O. Box 42, Al-Khod 123, Sultanate of Oman
}

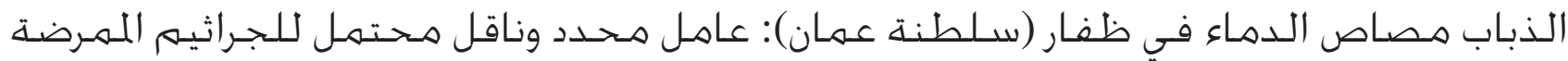

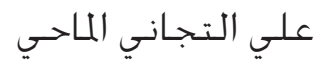

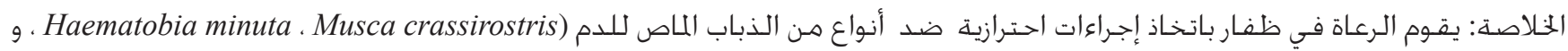
(Forcipomyia (Lasiohelea) whitcombei

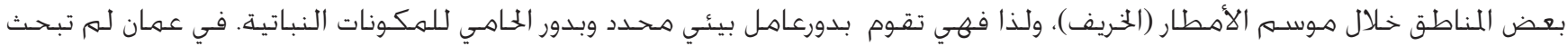

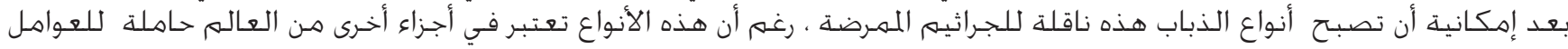

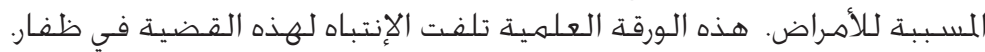

ABSTRACT: In Dhofar, pastoralists take certain precautionary measures against hematophagous flies: Haematobia minuta Bezzi, Musca crassirostris Stein and Forcipomyia (lasiohelea) whitcombei Boorman. Through their feeding on domesticated animals, these flies impede pasturing in certain areas during the rainy season (Khareef); hence they act as a limiting ecological factor and a custodian of the flora. The possibility that these flies could be potential pathogenic vectors has not been investigated in Oman, although in other parts of the world they are recognized as carriers of disease agents. The paper draws attention to this issue in Dhofar.

Keywords: Diptera, Muscidae, Ceratopogonidae, trypanosomiasis, ecological zones, mountains.

\section{Introduction}

This paper is the outcome of a field study in Dhofar undertaken in 2008, which documented the traditional pastoralists' precautionary measures against hematophagous flies. The documentation of pastoralists' practices in this respect is to facilitate the establishment of an analogy with ancient practices and explore the possible adaptation of prehistoric pastoralists in this ecoregion (ElMahi, 2010). Consequently, dealing in the field with the effect of flies on the life of pastoralists and animals made it obvious that the role of flies must be addressed. For that reason, this paper aims to cast light on these flies and their role as an ecological limiting factor in Dhofar. Furthermore, it is to trigger awareness of the possible potential role of flies as vectors transmitting disease-producing organisms to humans and uninfected livestock. But an overriding aim is to raise alarm about a potential menace that can seriously harm a developing region in the Sultanate.

Three hematophagous flies characterize the ecology of Dhofar's landscape: Haematobia minuta Bezzi (= Lyperosia minuta), Musca crassirostris Stein, and Forcipomyia (Lasiohelea) whitcombei Boorman (=Forcipomyia lasiohelea) (Mellor, 1978). The same information has been confirmed via personal communication by Mr. Salah Ageib (Ministry of
Agriculture and Fisheries, Salalah) and local informants. As the monsoonal climate shaped the characteristic ecological conditions of Dhofar, the changing seasons and tropical conditions created a suitable habitat for the hematophagous flies in question.

The effect of these flies on Dhofari pastoralists and the ecosystem as a whole became evident during the two seasons of the field study. The flies act as an ecological limiting factor that impedes pastoralism but yet is a factor in protecting Dhofar's flora. In particular, their possible role as a vector became clearly evident during the field investigations of 2008 and 2009. However, it would be useful first to take a closer look at the geography, climate and pastoral inhabitants of Dhofar.

\section{Dhofar}

The Dhofar Governorate occupies the southern part of the Sultanate of Oman (Fig. 1). The Empty Quarter, Rub Al-Khali marks its northern boundary with the rest of the Arabian Peninsula. The Arabian Sea marks its southern limits and Dhofar's mountain range extends from the east to the border with Yemen in the west.

Every year, from July to September, the seasonal southwest monsoon winds over the Indian Ocean cause low 


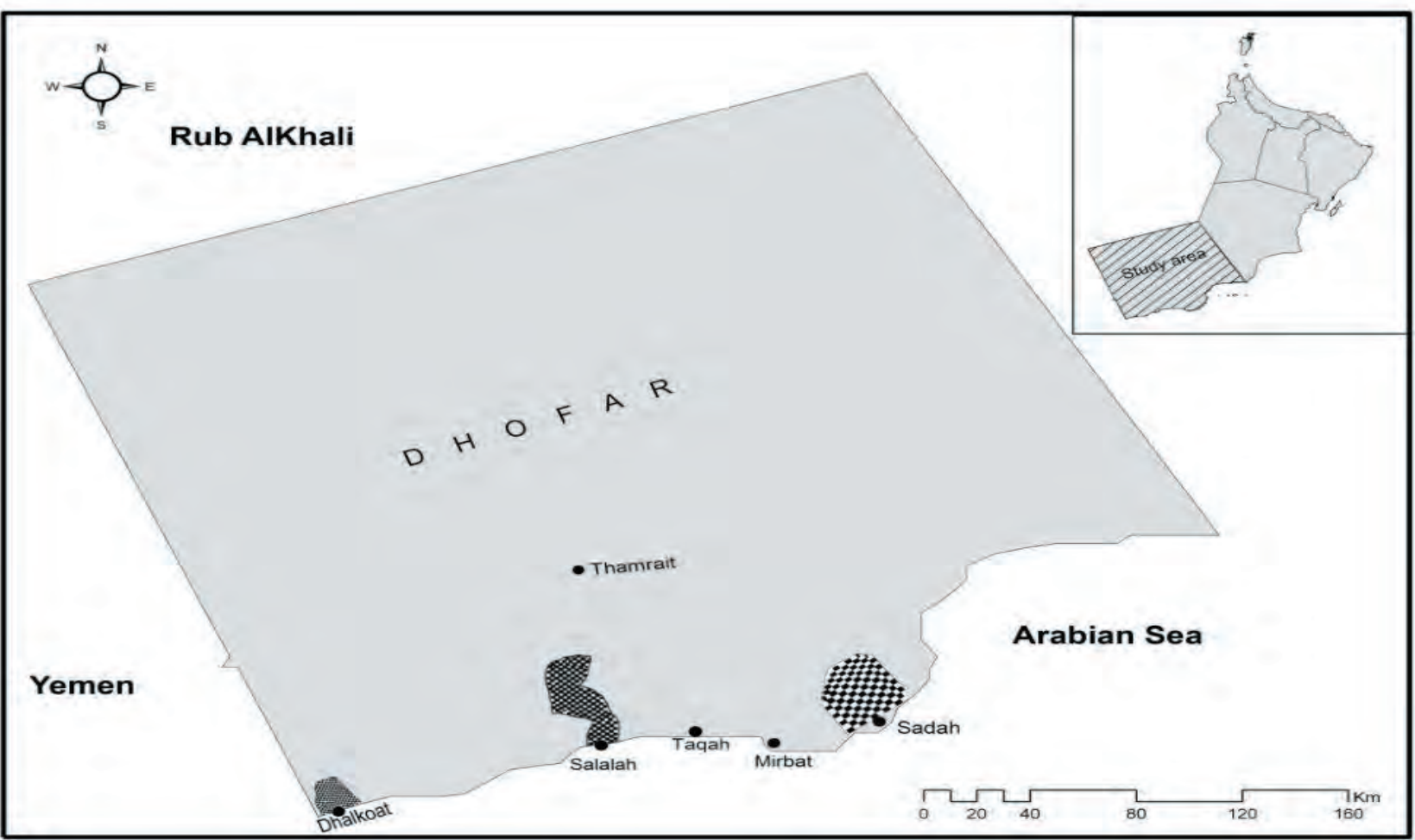

Figure 1. Study areas (checkered outlines corresponding to the three main mountain ranges in Dhofar, Oman (after El-Mahi, 2010).

clouds that eventually reach the mountains of Dhofar (Jabal Al-Qamar, Jabal Al-Qara and Jabal Samhan). These winds bring rain and drizzle fog to the mountain range creating a dense vegetation cover and tropical conditions. Temperatures drop and humidity ranges between 80 $100 \%$. The monsoon effect results in an average annual precipitation reaching $200-500 \mathrm{~mm}$ in the mountains and $110 \mathrm{~mm}$ on Dhofar's coastal plains. This unique season is known locally as Khareef, which is followed by a dry winter and summer.

The landscape of southern Dhofar is very much dominated by Jabal Al-Qara in the center, Jabal Al-Qamar in the west and Jabal Samhan in the east. Ecological conditions on Jabal Al-Qara are characterized by six ecological zones (Fig. 2) (Miller and Morris 1988; Ghazanfar 1992; Bahit, unpublished report, Department of

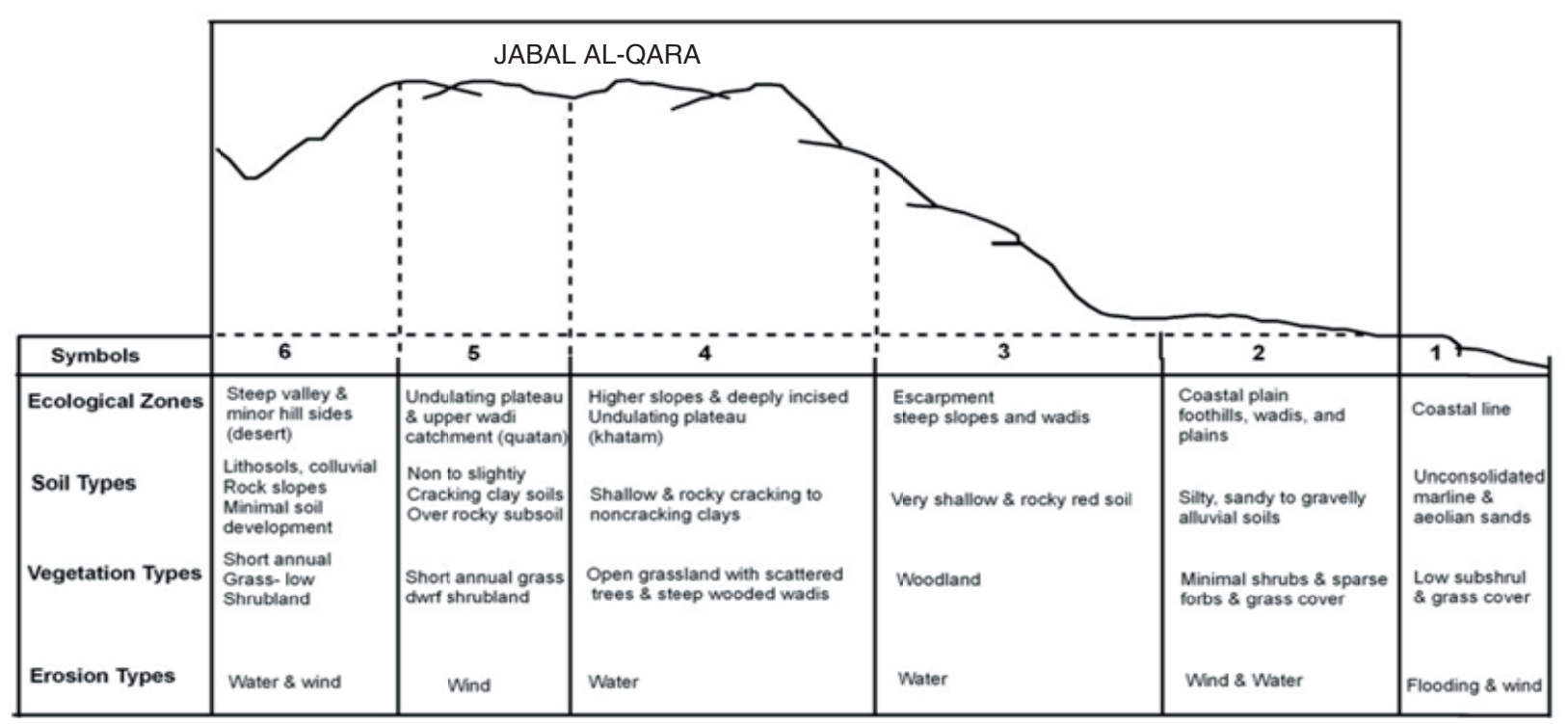

Figure 2. Six ecological zones of Jabal Al-Qara (after Miller and Morris, 1988; Ghazanfar, 1992; Bahit, unpublished report). 
Table 1. Ecological zones in Jabal Al-Qara (after Miller and Morris 1988; Ghazanfar 1992; Bahit, unpublished report).

\begin{tabular}{|c|c|c|}
\hline Zone & Name of the Zone & Characteristics of Plant Species \\
\hline 1 & Coastal plains & $\begin{array}{l}\text { Low sub-shrub and grass cover: Avicennia marina, Acacia tortilis, Zizihus teucadermis, Tamarix } \\
\text { aphylla, Cadaba baccarinil, Cadaba farinose, Commiphora spp., Caesalpinia erianthera, } \\
\text { Adenium abesum, Euphorbia spp., Aloe dhofarense, Aole inermis. }\end{array}$ \\
\hline 2 & Foothills & $\begin{array}{l}\text { Minimal shrubs, sparse forbs and grass cover: Boscia arabica, Comintphora spp., Grewia spp., } \\
\text { Croton confertus and Jatropha dhofarica.. }\end{array}$ \\
\hline 3 & Escarpment (with 5 minor zones) & $\begin{array}{l}\text { Woodland: Acacia Senegal, Commiphora spp., Mytenus dhofarica, Croton confertus and } \\
\text { Blepharispermum hirtum.. Delonix elata. Anogeissus dhofarica, Sterecutia africana lanea sp. } \\
\text { Cissus quadrangularis. Ficus spp, Ziziphus-spina-christi and Acacia nilotica trees. }\end{array}$ \\
\hline 4 & Khatam & $\begin{array}{l}\text { Open grassland, scattered trees and steep wooded wadis: Olea, Anogeissus and Dodonaea, } \\
\text { Euphorbia balsamifera and Commiphora spp. }\end{array}$ \\
\hline 5 & Qatan & $\begin{array}{l}\text { Short annual grass and dwarf shrubs: Acacia etbalica, dracena serulata and Commiphora } \\
\text { serulata. }\end{array}$ \\
\hline 6 & Najed & $\begin{array}{l}\text { Desert and short annual grass- low shrub land: Boswellia sacra, Acacia etbalica and Nonorhops } \\
\text { richiana }\end{array}$ \\
\hline
\end{tabular}

Pasture and Range, Ministry of Agriculture and Fisheries, Sultanate of Oman) in ElMahi (2001). Table 1 illustrates the types of vegetation in each zone.

Pastoralism remains a traditional occupation in Dhofar and the principal animals in this ecoregion are cattle, camel and goats. Interestingly, the animals and their ecological requirements have forced some sort of geographical distribution on their owners. Hence, goat pastoralists seasonally occupy particular territories with characteristic ecological conditions that suit their animals' requirements. The same holds for cattle and camel pastoralists. All in all, Dhofari pastoralists are well adjusted to the environmental conditions and their pastoral management of the herds and seasonal movements are strictly traditional, which reflects their essential indigenous knowledge, ways and adaptation.

\section{The Flies}

In August 1977, P.S. Mellor from Britain's Animal Virus Research Institute at Pirbright in Surrey visited Dhofar to investigate what is known locally as the 'black fly' H. minuta. The fly was reported by Mellor (1978) to be a serious menace and a constant stress on livestock during the rainy season. This was the first investigation that addressed the presence and effect of bloodsucking flies in Dhofar.

Three flies of the order Diptera: H. minuta, $M$. crassirostris and $F$. whitcombei have been identified (Mellor, 1978; Ageib, personal communication). Locally, H. minuta is known as the 'black fly,' $M$. crassirostris as 'kieszet' and $F$. whitcombei as 'arnut.' These bloodsucking flies are terrestrial and appear during the rainy season (Khareef) between July and September in the three major areas: Jabal Al-Qamar, Jabal Al-Qara and Jabal Samhan (Fig. 3). Their habitat has been recorded as extending across four zones namely Qatan, Khatam, escarpment and foothills (Fig. 3) (ElMahi, 2010).

The flies (H. minuta, M. crassirostris) are known to use pats of cattle dung for oviposition (Fig. 4) and their mature larvae pupate in the damp soil below (Mellor, 1978). M. crassirostris was reported to be a serious cattle pest in India and inflicted severe bites on livestock there (Patton, 1992). On the other hand, Debenham (1983) describes $F$. lasiohelea as a similar nuisance to cattle in Australia. According to Reye (1964), the larvae of F. lasiohelea were found in rotten plants and damp places and they fed on fungi in decomposing plants. Forcipomyia whitcombei is a true ecological limiting factor in the Dhofari ecosystem. It is commonly known among local pastoralists to suck blood voraciously and cause irritation and an allergic response in man and animals.

From another ecological facet, the flies protect Dhofar's flora. The lush vegetation that characterizes the landscape (Fig. 5) has been protected from very early times by these flies. If it was not for them, man would have expanded and exploited the flora of the region to a greater extent. Timber and perennial plants (Fig. 6), excessive grazing and land use would have been the main focus of man's exploitation (Fig. 7). To illustrate, a good example is Dhofar's coastal plains and the plains (Jarbib) where the main complaint by government agents is overgrazing and the degradation or disappearance of certain plant species (Ageib, unpublished report in Arabic).

The threat caused to pastoral groups and livestock is unequivocal. On his visit to Dhofar, Mellor (1978) reported that these flies (H. minuta and $M$. crassirostris) attacked individual cattle in large numbers as high as 500. He also observed that most cattle carried ca. 5 to 200 flies at any one time (Mellor, 1978). As for the effect Mellor (1978) reports the following: "Some animals, those 


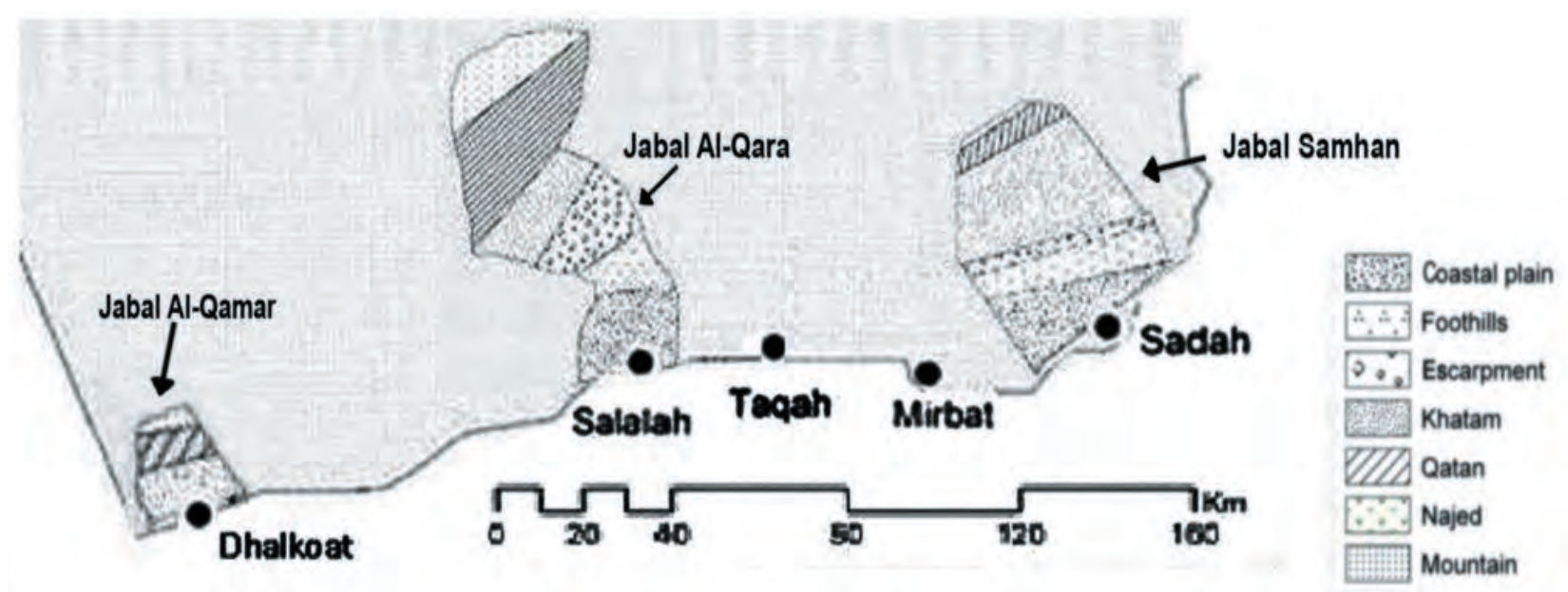

Figure 3. Close-up of study areas shown in Figure 1 illustrating ecological zones in the three mountain ranges of Dhofar (after ElMahi, 2010).

which looked to be in poor condition, had particularly heavy infestations. However, few overt lesions directly attributable to fly bites were seen, although one Boran bull had a circular lesion about $4 \mathrm{~cm}$ in diameter on the left side of the hump. This area had a serosanguinous exudates and was surrounded by thickly clustered Lyperosia."

\section{Pastoralists' Precautionary Measures Against the Flies}

In response to the hazard and stress caused by these flies, Dhofar's pastoral groups take certain measures against them and make adjustment in their adaptation. Without such measures, neither herders nor their animals would have survived in these habitats during rainy seasons. Nonetheless, the measures adopted are designed to evade the flies and not to confront them. Herders have no other means but to impede contact between their animals and the flies. In essence, it is an adaptation shaped by human ingenuity and culture intended to secure survival.

Three measures in particular are adopted by the cattle herders. The first rests on the simple fact that the flies are diurnal. Accordingly, herders allow their animals to graze only at night. It is a well-observed practice that animals graze after sunset and not before. Thus, the pastoralists have forced diurnal animals to become nocturnal, a triumph of culture over nature dictated by ecological stress.

The second measure is to keep animals inside enclosures that are completely dark during the day. These are designed and built (of rocks and timber) to prevent any daylight getting in (Fig. 8). The animals are kept in the enclosures for the whole day and are only taken out after sunset. While the animals are grazing, the herders clean the floors. During the day, they also collect all manure within the vicinity of their houses and this is divided into two portions. One is burned inside the animal enclosure, where its smoke acts as a fly repellent and the other is dried and used as bedding in the animal enclosure.

Mellor (1978) reports that H. minuta lay their eggs in cattle manure, where the mature larvae use the damp soil under the dung to pupate. He goes further to describe how their pupae "overwinter" under pats of animal manure, while, $M$. crassirostris has a life cycle similar to $H$. minuta, and uses cattle manure for breeding.

Apparently, by keeping the settlement and its surroundings clean of animal manure, herders are restricting oviposition habitats for the flies. It is clear that this measure affects the flies' density and numbers in the vicinity of the animal enclosures and settlements.

The third precautionary measure rests on seasonal movements. Two types of movement are adopted by Dhofari pastoral groups, namely, transhumant seasonal movements and cyclical ones. These are geared in response to the different seasons and their intensities. Winter and summer impose certain conditions on the herders and their animals, while the rainy season (Khareef) imposes completely different ones. These cannot be ignored or resisted by the pastoralists. Table 2 illustrates the movements of each principal animal herd in response to seasonal requirements (ElMahi, 2010).

Like all pastoral societies, Dhofari pastoral groups gear their movements towards the welfare of their animals. Cattle, camels and goats are moved seasonally to achieve the following objectives: (a) search for pasture, (b) avoid wet conditions caused by the Khareef, and (c) avoid disturbing bloodsucking flies.

Elderly herders confirm that they move their animals seasonally to avoid the harmful flies. They even go further to say that their animals seem to be aware of the flies and the harm they can inflict. Therefore, animals avoid areas infested by the flies (Fig. 9). As stated by one of elderly informants: 


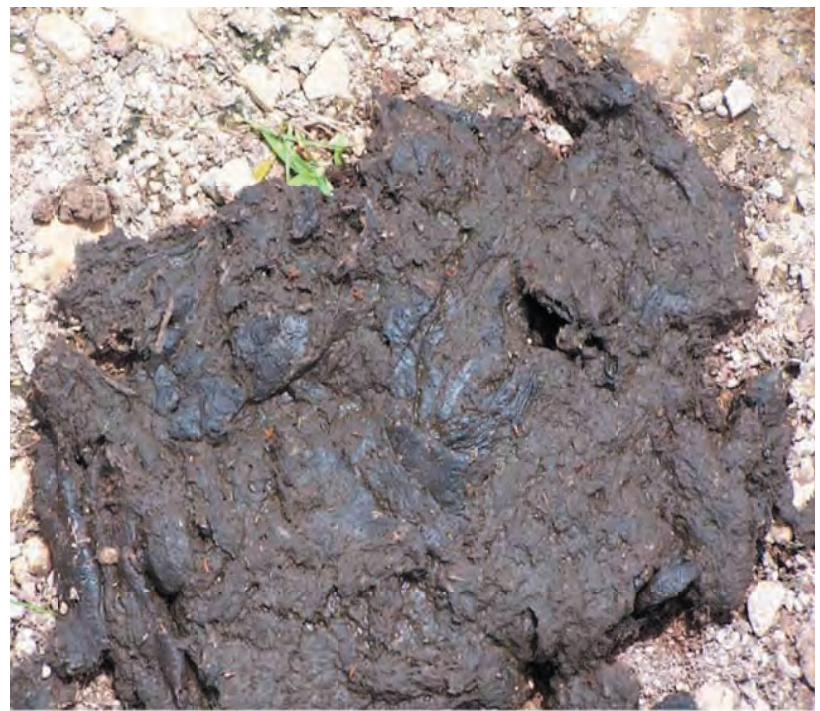

Figure 4. H. minuta and M. crassirostris use pats of cattle dung to oviposit and later mature larvae pupate in the damp soil below.
"There is nothing to be done, we just need to cope with it."

\section{A Limiting Factor}

In spite of these precautionary measures, the flies are a dangerous menace in their environment and a limiting factor. In an ecological sense, a limiting factor is an environmental factor that can hamper and weaken an organism. Such a limiting factor can substantially restrict its population growth and reduce its geographical distribution, range, and activity (Odum, 1971).

The work by Krinsky (1976) and Foil (1989) cast light on the animals' productivity under the stress of bloodsucking flies and relates it to a predisposition to infection and aggravation and loss of blood which results in poor conditions and noticeable weight loss. In addition, Patton (1992) reports that $M$. crassirostris as a pest has a bearing on the quantity of cow's milk in India.

Examining a number of animals in Dhofar, Mellor (1978) described how some were in poor condition as a

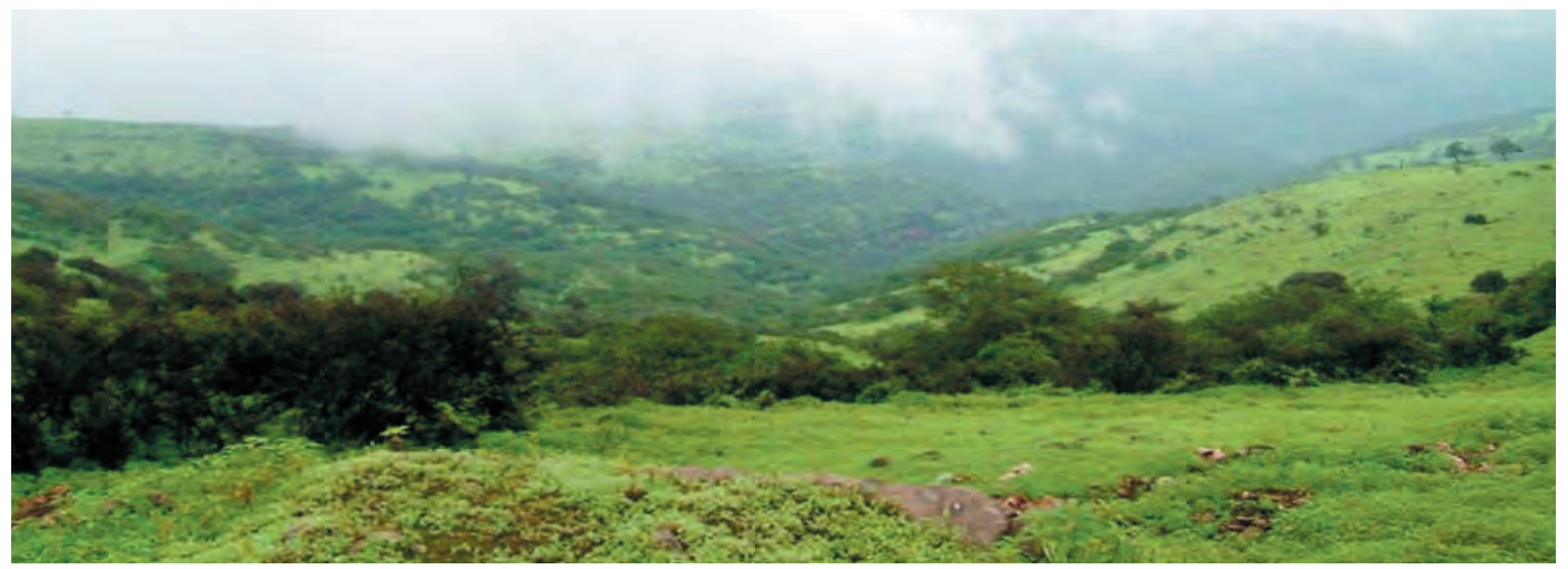

Figure 5. Lush vegetation characterizes Dhofar's landscape during the khareef.

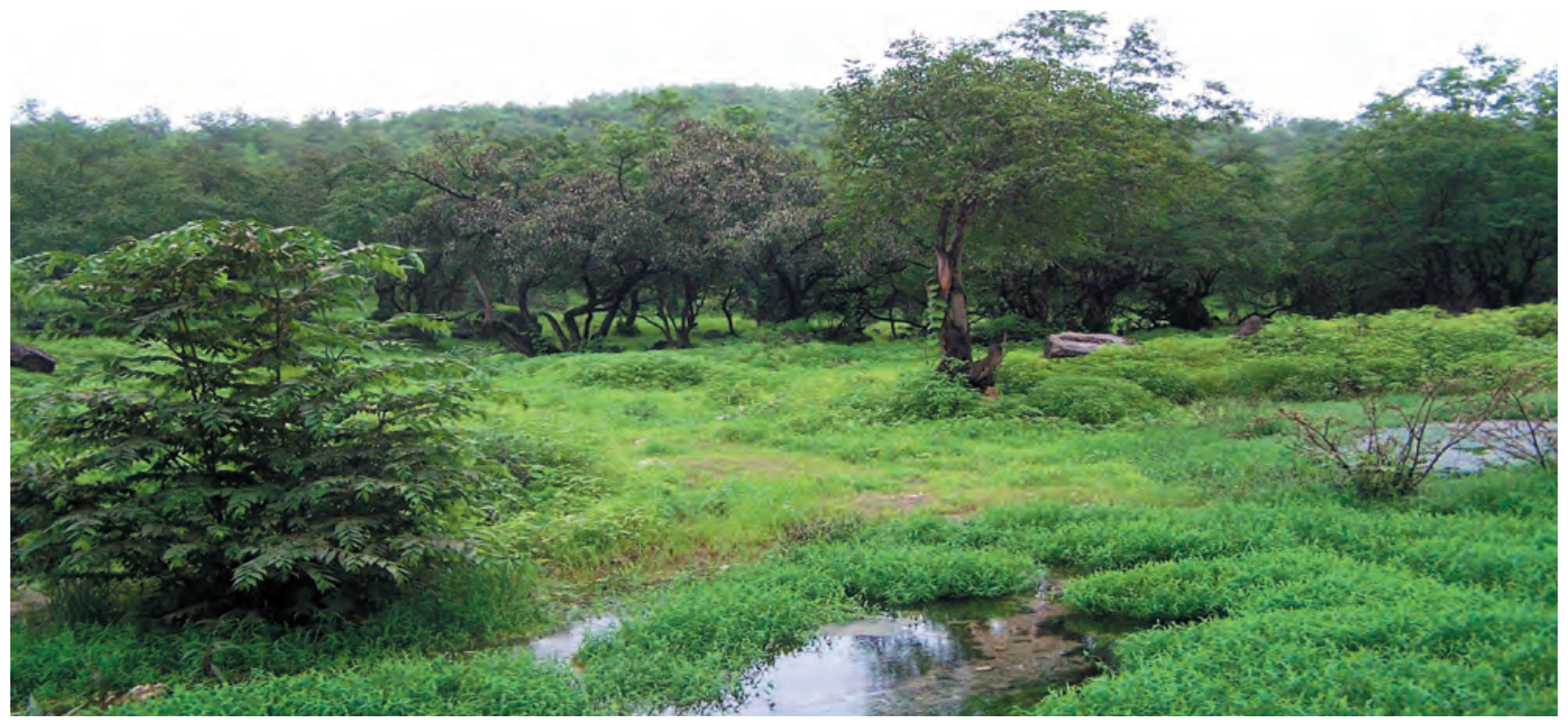

Figure 6. Trees and perennial plants in Dhofar. 


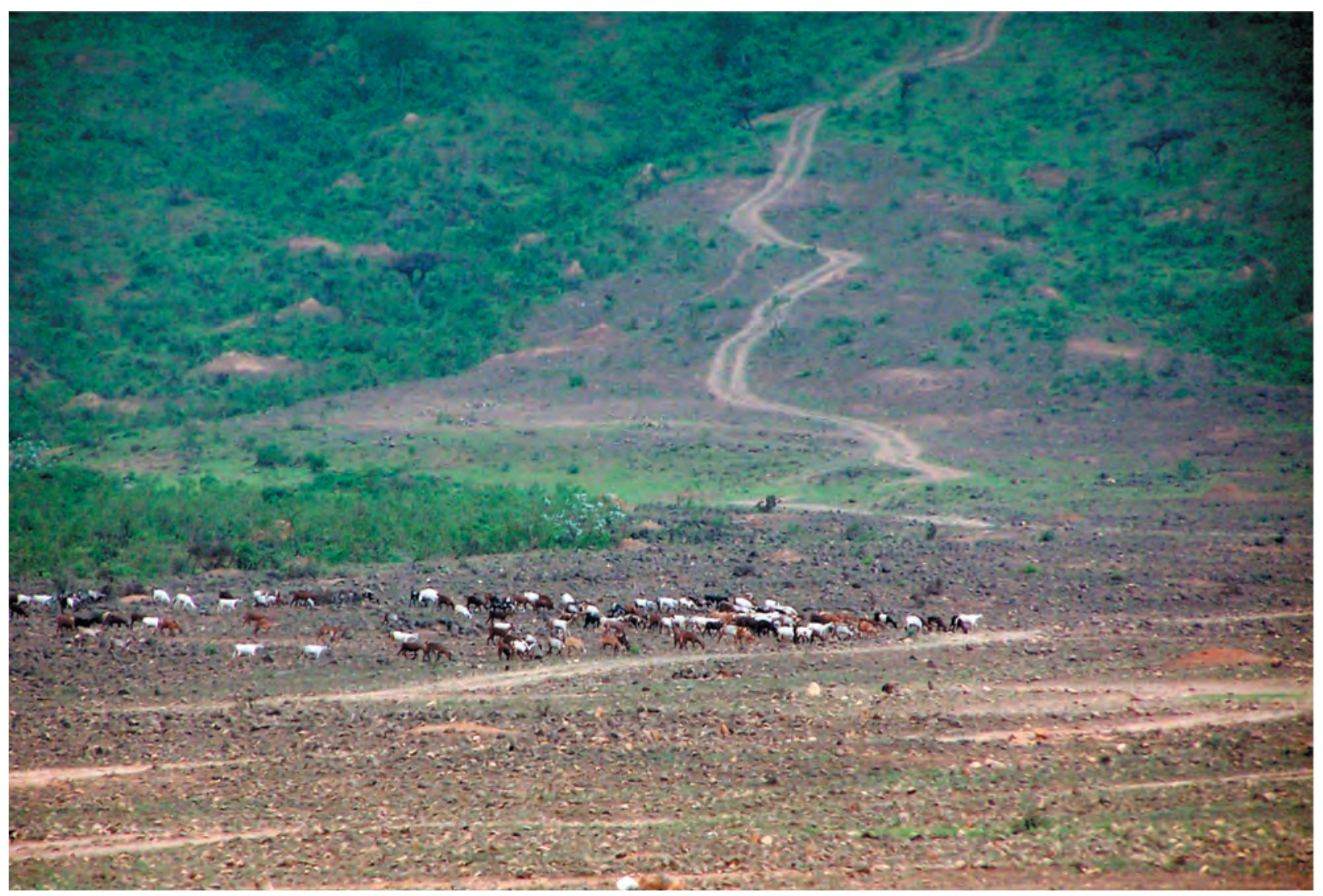

Figure 7. Excessive grazing.
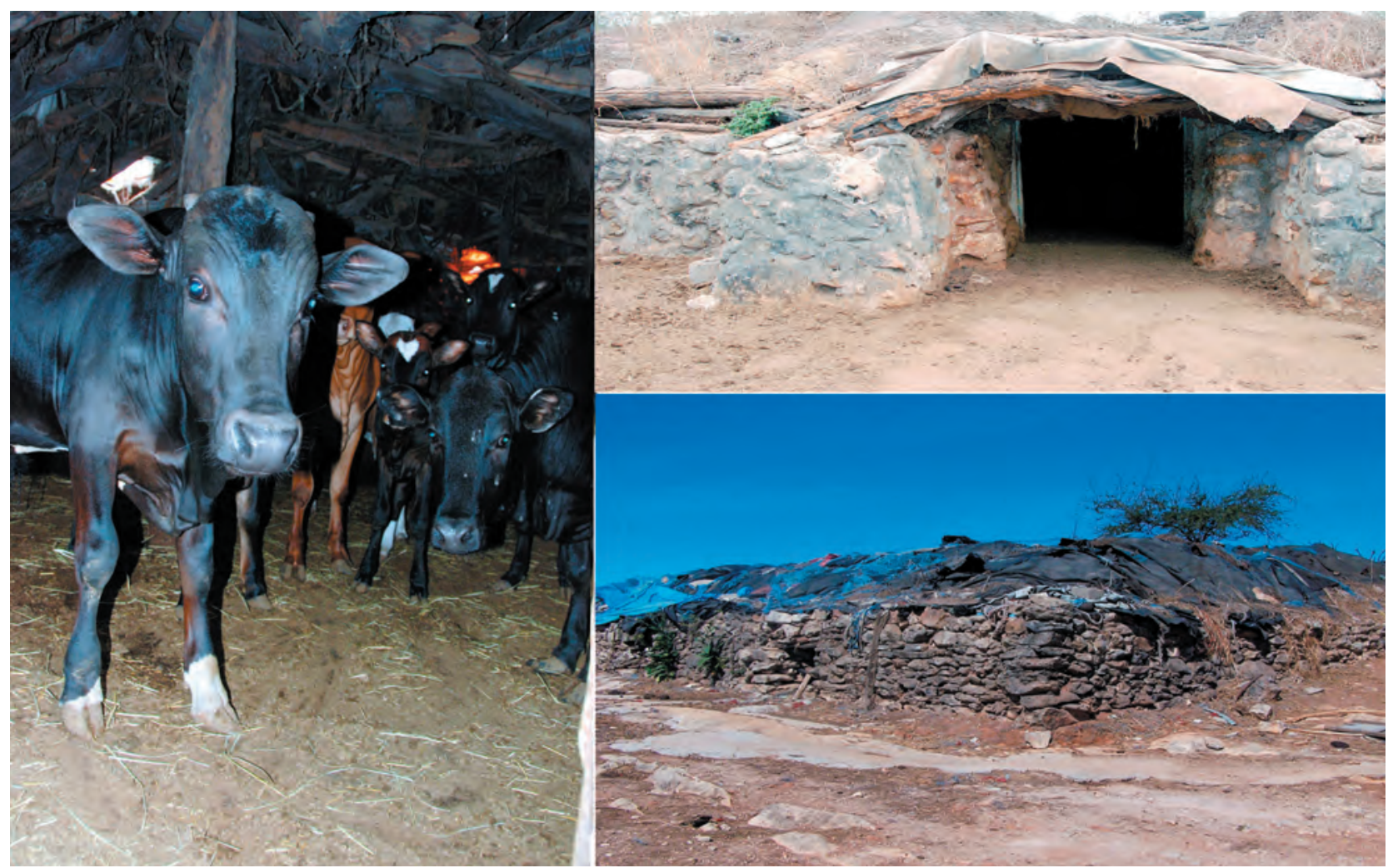

Figure 8. Cattle enclosure. 
Table 2. Animal movement in different seasons (after ElMahi, 2010).

\begin{tabular}{lll}
\hline Season & Animal & $\begin{array}{l}\text { Area of Distribution North and } \\
\text { South of Jabal Al Qara }\end{array}$ \\
\hline Winter/summer & Cattle & Khatam and Qatan \\
Winter/summer & Camels & Foothills and Qatan \\
Winter/summer & Goats & Foothills and escarpment \\
Khareef & Cattle & $\begin{array}{l}\text { Qatan, Khatam, foothills and } \\
\text { occasionally coastal plains. }\end{array}$ \\
& Camels & Coastal plains and Najed \\
Khareef & Goats & Foothills, coastal plains and Najed \\
Khareef & & \\
\hline
\end{tabular}

result of physical injury and heavy infestation. It is also possible to assume that such negative effects can equally imperil the herd's size. It hinders productive and preproductive individuals, both of which constitute the herd's future.

Viewing the landscape ecology of Dhofar, one notices that pastoralists are restricted from exploiting the wide range of pastures available. They simply cannot take their animals to graze far from the enclosures which protect them from the flies during the day. Therefore, their range is restricted (Fig. 10).
In addition to possible negative health effects on their animals, economically the pastoralists of Dhofar are unable to expand either horizontally or vertically. They cannot utilize other areas of pasture and extend the range of pasture due to the fact that their animals must be protected in pitch-dark enclosures. Consequently, confinement to the surroundings of the settlements leads to a limited number of animals being kept by the pastoral groups. They are aware of the carrying capacity of their surroundings and thus keep a reasonable number of animals that will balance available pasture in a limited domain. Elderly informants state that increasing their cattle numbers will result in lower milk production. Accordingly, it seems that the flies are limiting both cattle populations and economic expansion.

\section{Potential Vectors}

So far there is no record of $H$. minuta, M. crassirostris and $F$. whitcombei vectoring pathogens to livestock in Dhofar. Perhaps this can be explained by the fact that beyond Mellor's solitary study, these flies have not been comprehensively researched. Another explanation is that so far no infected animals have been introduced into Dhofar.

On the other hand, the same flies have been reported from different parts of the world as potentially infective vectors. Bellis et al. (2004) reported from Australia that

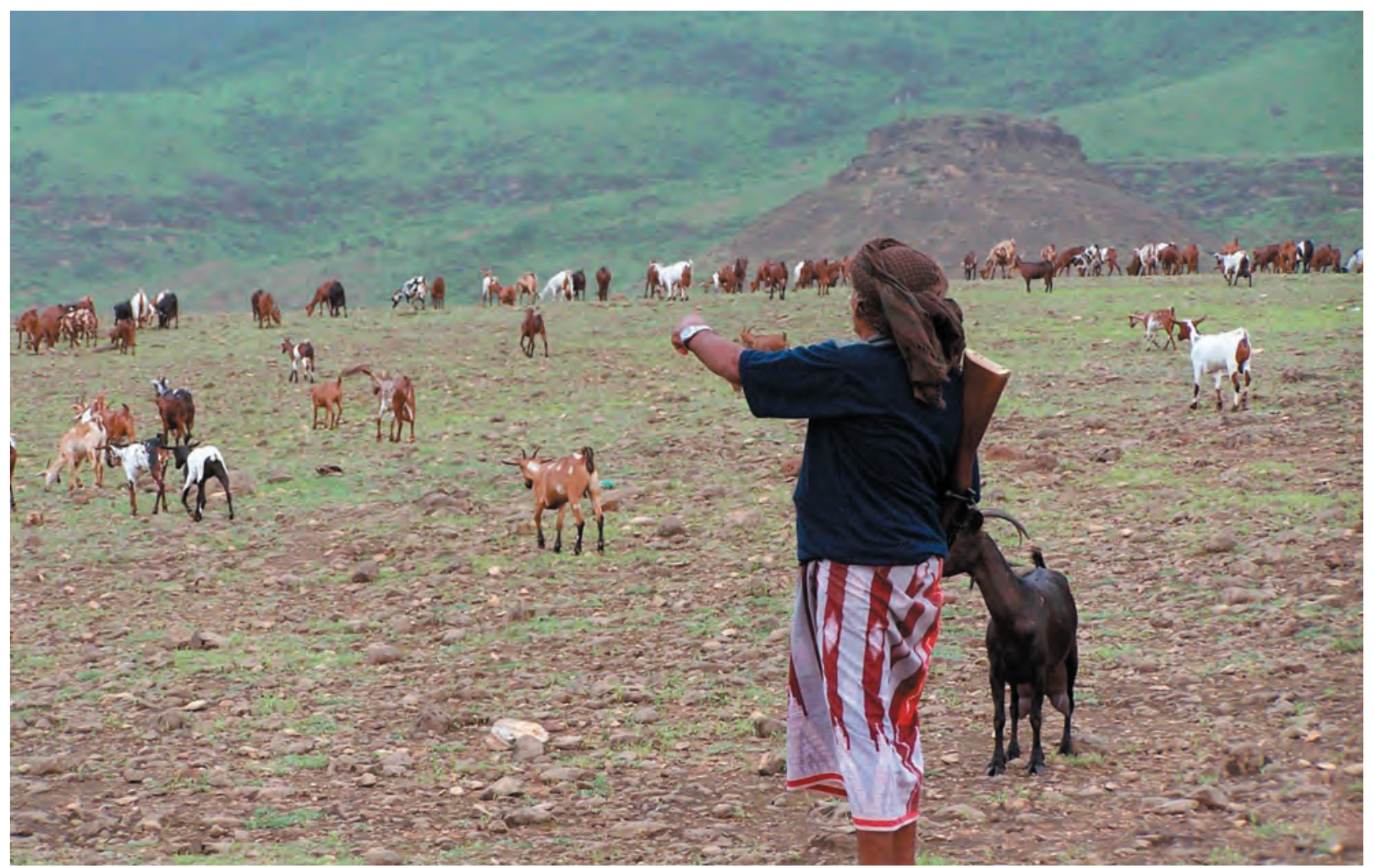

Figure 9. Animals are aware of the flies' boundaries. 


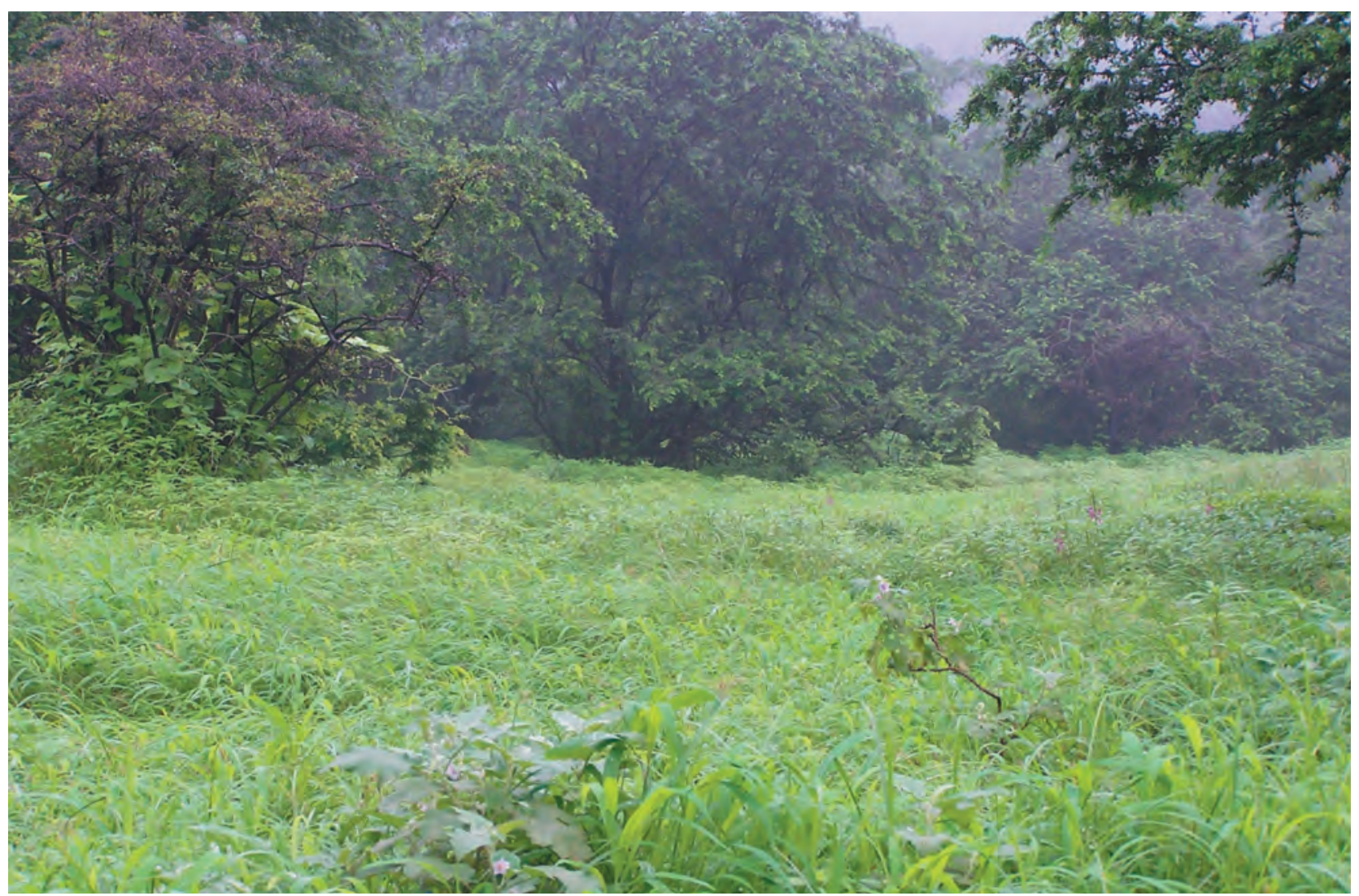

Figure 10. Large grazing areas protected by the flies.

bloodsucking ceratopogonid flies (of the same family as F. whitcombei) are pests that can transmit diseases and parasites to livestock. Moreover, F. lasiohelea is described as a cattle-biting fly and a potential vector of animal disease (Debenham, 1983).

In Africa, a fly survey carried out in Ethiopia by Shineshaw et al. (2005) refers to biting flies and mentions that Kigaye and Jiffar (1991) also report from the south eastern part of Ethiopia ten species including $H$. minuta. In addition, Shineshaw et al. (2005) reported that these biting pests transmit Trypanosma and transmit other livestock diseases. Again, Mellor et al. (1975) suggests that $H$. minuta is a potential vector of livestock disease.

Now, given the presence of these flies in Dhofar, to what extent is the region vulnerable? Adam (Veterinary Laboratory, Salalah Hospital, personal communication) responds to this question by stressing that trypanosomiasis was diagnosed in camels twelve years ago in Dhofar. In May 2008, it spread in a sporadic form among camels in Wilayat Mirbat. Later on, it spread as an epidemic among camel herds in Wilayat Sadh during the first half of 2009 (Fig. 1). According to Adam (personal communication), no work has been carried out to determine the vector responsible for these outbreaks.

Dhofar's situation is perhaps comparable to that observed in Queensland, Australia; and comments by Reye (1964) might well be relevant. "All bloodsucking arthropods must be suspect as potential vectors of disease, and the midges are no exception. No disease transmission by midges has been proved for Queensland, but elsewhere they have been proved vectors of such organisms..."

Despite current uncertainty, Dhofar's vulnerability cannot be ignored, especially since it is commercially and culturally linked with different parts of the world. It is also a route of many migratory birds.

If pathogens transmittable to humans and animals are introduced into Dhofar, the impact will certainly extend to other sectors such as public health and areas of the economy such as the tourism industry. The region's hematophagous flies could put all these sectors at risk.

\section{Conclusion}

Given the overall situation described above, it seems obvious that Dhofar is vulnerable because hematophagous insects in other regions can transmit assorted pathogens to humans, wildlife and domestic animals. But at present, there are no detailed investigations that address this issue. A priority must be to discover whether these flies can act as vectors of arboviruses to human and animal populations. Further, we should ask what are the portals that can allow infected animals into the region. And how might they be monitored and scrutinized? It would be unwise to wait until cases of pathogen transmission by biting flies occur among humans and livestock on a large scale. 
An immediate and in-depth investigation of this matter is recommended. It is to enhance our understanding of hematophagous flies in Dhofar and establish a proper basis for coherent plans against any human and veterinary health hazards that can possibly take place in this region.

\section{Acknowledgements}

This research project (IG/ART/ARCH/08/01) has been fully financed by Sultan Qaboos University. The author is indebted to Sultan Qaboos University.

My colleagues Nasser Hamd Al-Henahi (Department of Archaeology, SQU), Salah Ageib (Ministry of Agriculture, Salalah) and Adam Mohamed Adam (Veterinary Laboratory, The Veterinary Hospital Salalah) have been of great assistance. Professor Adrian Roscoe (Department of English, SQU) kindly did the proofreading. The author is indebted to them.

\section{References}

Bellis, G.A., L.F. Melville, N.T. Hunt, and M.N. Hearnden. 2004. Temporal activity of biting midges (Diptera: Ceratopogonidae) on cattle near Darwin, Northern Territory, Australia. Veterinaria Italiana 40:324-328.

Debenham, M.L. 1983. Australasian species of the blood-feeding Forcipomyia subgenera, Lasiohelea and Dacnoforcipomyia Diptera: Ceratopogonidae). Australian Journal of Zoology Supplementary Series 31:1-61.

ElMahi, A.T. 2010. Pastoralists adjustment to Hematophagous flies in Dhofar: An analogy of an ancient adaptation. Adumatu 21:15-32.

ElMahi. A.T. 2001. Traditional Dhofari Pastoral groups in Oman: A parallel of an ancient Cultural Ecology. Proceedings of the Seminar of Arabian Studies 31: 131-143.

Foil, L.D. 1989. Tabanids as vectors of disease agents. Parasitology Today 5:88-96.
Ghazanfar, S.A. 1992. An Annotated Catalogue of the Vascular Plants of Oman and their Vernacular Name. Scripta Botanica Belgica 2 Meise.

Kigaye, M.K. and T. Jiffar. 1991. A survey of ectoparasites of cattle in Harar and Dire Dawa districts, Hararghe administrative region of Ethiopia. Bulletin of Animal Health and Production in Africa 39:15-24.

Krinsky, W.L. 1976. Animal disease agents transmitted by horse flies and deer flies (Diptera: Tabanidae). Journal of Medical Entomology 13:225-275.

Mellor, P.S. 1978. Biting flies attacking cattle in the Dhofar province of the Sultanate of Oman. Tropical Animal Health and Production 10:167-169.

Mellor, P.S., J. Boorman, and M. Jennings. 1975. The multiplication of African horse-sickness virus in two species of Culicoides (Diptera, Ceratopogonidae). Archives of Virology 47:351-356.

Miller, A.G. and M. Morris, M. 1988. Plants of Dhofar, the Southern Region of Oman. Traditional, Economic and Medical Uses. The Office of the Adviser for Conservation of the Environment, Diwan of Royal Court, Sultanate of Oman.

Odum, E.P. 1971. Fundamentals of Ecology. W.B. Sanders Company, London.

Patton, W.S. 1992. Notes on the Species of the Genus Musca, LINNAEUS - Part I: 411-426. http: //hbs.bishopmuseum.org/fiji/pdf/patton1922.pdf

Reye, E.J. 1964. The problems of biting midges (Diptera: Ceratopogonidae) in Queensland. Australian Journal of Entomology 3:1-6.

Shineshaw, A., G. Abebe, and M. Desquesnes. 2005. Epidemiology of mechanically transmitted Trypanosomosis (Trpanosoma vivax) of domestic animals in three districts bordering, Lake Tana, Ethiopia. Twenty Eighth Meeting 28th Reunion Addis Ababa, Ethiopia, 26 September 2005.

Received: October 13, 2009

Accepted: May 30, 2010 